\title{
Nurmisäilörehun korjuu - pitkän aikavälin taloustarkastelu
}

\author{
Timo Sipiläinen ${ }^{1)}$, Matti Ryhänen ${ }^{2)}$ \\ ${ }^{1)}$ Helsingin yliopisto, Taloustieteen laitos, PL 27, 00014 Helsingin yliopisto, \\ etunimi.sukunimi@helsinki.fi \\ ${ }^{2)}$ Seinäjoen ammattikorkeakoulu, SeAMK Elintarvike ja Maatalous, Ilmajoentie 525, 60800 Ilmajoki, \\ matti.ryhanen@seamk.fi
}

\section{Tiivistelmä}

Nurmisäilörehun tuotannon taloudellisuuden arviointi on monitahoinen kysymys. Tarkastelua mutkistavat useat nurmisäilörehun tuotantoon ja käyttöön liittyvät seikat: Nurmirehu korjataan samalta alalta useita kertoja kesässä. Nurmisadon määrä ja laatu muuttuvat korjuuajan mukaan eritavoin eri korjuukerroilla. Edellinen korjuukerta vaikuttaa seuraavaan. Säilörehun tuotantoon ja korjuuseen liittyvän dynamiikan lisäksi tilatason päätöksentekoon vaikuttaa olennaisesti tarkastelun aikajänne. Erilaisissa päätöstilanteissa ja toimintaympäristöissä paras ratkaisu voi olla erilainen. Maidontuottajan pitkän aikavälin strategia määrittää, minkä verran hän varaa säilörehualaa, milloin korjaa, millaisen korjuuketjun varaan tuotantonsa rakentaa ja tekeekö yhteistyötä. Kasvukauden säätä ja sadon kehitystä ei tiedetä etukäteen, joten maidontuottajan on operatiivisin päätöksin ohjattava vuosittaista toimintaa kohti haluttua lopputulosta. Sisäruokintakauden rehujen käyttö optimoidaan, kun tiedetään varastoidun säilörehun määrä ja laatu.

Tässä tutkimuksessa kehitettiin malli, joka soveltuu säilörehun tuotannon pitkän aikavälin taloudelliseen suunnitteluun. Mallin avulla voidaan verrata eri säilörehun korjuuketjujen keskinäistä edullisuutta ja tarkastella, milloin urakoitsijan käyttö on taloudellisesti edullisin vaihtoehto. Mallia laadittaessa oletettiin, että kaikilla korjuuteknologioilla voidaan tuottaa säilönnälliseltä laadultaan moitteetonta rehua. Mallilla voidaan $\mathrm{mm}$. tarkastella, miten säilörehun $\mathrm{D}$-arvon muutos vaikuttaa taloudelliseen tulokseen tai millainen tulos korjuuyhteistyössä voidaan saavuttaa suhteessa omaan korjuuketjuun. Perusmallit laadittiin eteläpohjalaisille esimerkkimaitotiloille.

Laskentamallissa ei rajoitettu ennalta työmäärää, korjuuseen kuluvaa aikaa tai peltoalaa. Pitkän aikavälin tarkastelussa rehunkorjuun kohtuullinen viivästyttäminen pienentää ylijäämää vain vähän. Mallin tulosten mukaan halvin korjuuketju tuotti parhaan taloudellisen tuloksen, vaikka rehunkorjuu oli hidasta muihin korjuuketjuihin verrattuna. Korjuuketjujen ylijäämien erot pienenevät tilakoon kasvaessa. Erityisesti korjuuteholtaan suurten ketjujen hyödyntäminen suosii tilojen välistä yhteistyötä tai urakoitsijan käyttöä. Lohkojen etäisyydellä tilakeskuksesta on merkittävä vaikutus taloudelliseen tulokseen, joten tämänkin perusteella tilusrakenteen parantamiseen kannattaa kiinnittää huomiota.

Tilastollisesti käsitellyn Etelä-Pohjanmaalta kerätyn maitotila-aineisto mukaan rehun sulavuudella ja maitotilan teknisellä tehokkuudella on positiivinen yhteys. Siten D-arvoltaan hyvälaatuisella rehulla tuottavuus paranee. Positiivinen yhteys kuitenkin häviää, kun tarkastellaan rehun sulavuuden ja kustannustehokkuuden välistä yhteyttä. Korkean D-arvon rehun tuottaminen aiheuttaa lisäkustannuksia, joiden kattamiseen syntyneet lisätuotot kuluvat. Tulos voidaan esittää myös siten, että tilan kannalta parhaan taloudellisen tuloksen tuottava tapa toimia ei välttämättä ole tuottavuudeltaan paras.

Asiasanat: strategia, taloudellinen tulos, korjuuketju, korjuuaika 


\section{Johdanto}

Erilaisissa päätöstilanteissa ja toimintaympäristöissä maidontuotantoon liittyvät optimiratkaisut voivat vaihdella. Kun päätöksenteon kehikkona on pitkän aikavälin strategia, yritystoimintaa kehitettäessä päätetään, minkä verran säilörehualaa varataan, milloin korjataan, millaisen korjuuketjun varaan tuotanto rakennetaan ja tehdäänkö yhteistyötä. Kasvukauden säätä ja sadon kehitystä ei tiedetä etukäteen, joten maidontuottajan on lyhyen aikavälin päätöksillä ohjattava vuositason toimintaa kohti toivottua lopputulosta. Sisäruokintakauden rehujen käyttö voidaan puolestaan optimoida taloudellisesti tilanteessa, jossa varastoidun säilörehun määrä ja laatu tiedetään. Käytännössä maidontuottaja tekee siten kolmentasoisia päätöksiä: miten järjestää sisäruokintakauden ruokinta taloudellisesti optimaalisesti varastossa olevien rehujen puitteissa, miten järjestää tulevan vuoden kasvinviljely ja lehmien ruokinta taloudellisesti optimaalisesti ja miten järjestää säilörehuntuotanto ja eläinten ruokinta maitotilan kokonaisuuteen sopivaksi, jotta taloudellinen tulos on pitkällä aikavälillä paras mahdollinen.

Vaikka lyhyen aikavälin suunnittelun apuvälineitä on olemassa, strategisen, pitkän aikavälin suunnittelun apuvälineistä on niukkuutta. Tämän tarkastelun lähtökohtana on pitkän aikavälin näkökulma, jossa etsitään vaihtoehtoja järjestää säilörehun tuotantoprosessi maitotilan kokonaisuuteen sopivaksi niin, että saadaan paras mahdollinen taloudellinen tulos. Tarkastelu perustuu vaihtoehtoisten säilörehun korjuuketjujen vertailuun lehmämäärältään erikokoisilla tilatyypeillä, joilla peltoala saattaa vaihdella mm. valitun korjuutavan mukaan (kuvio 1).

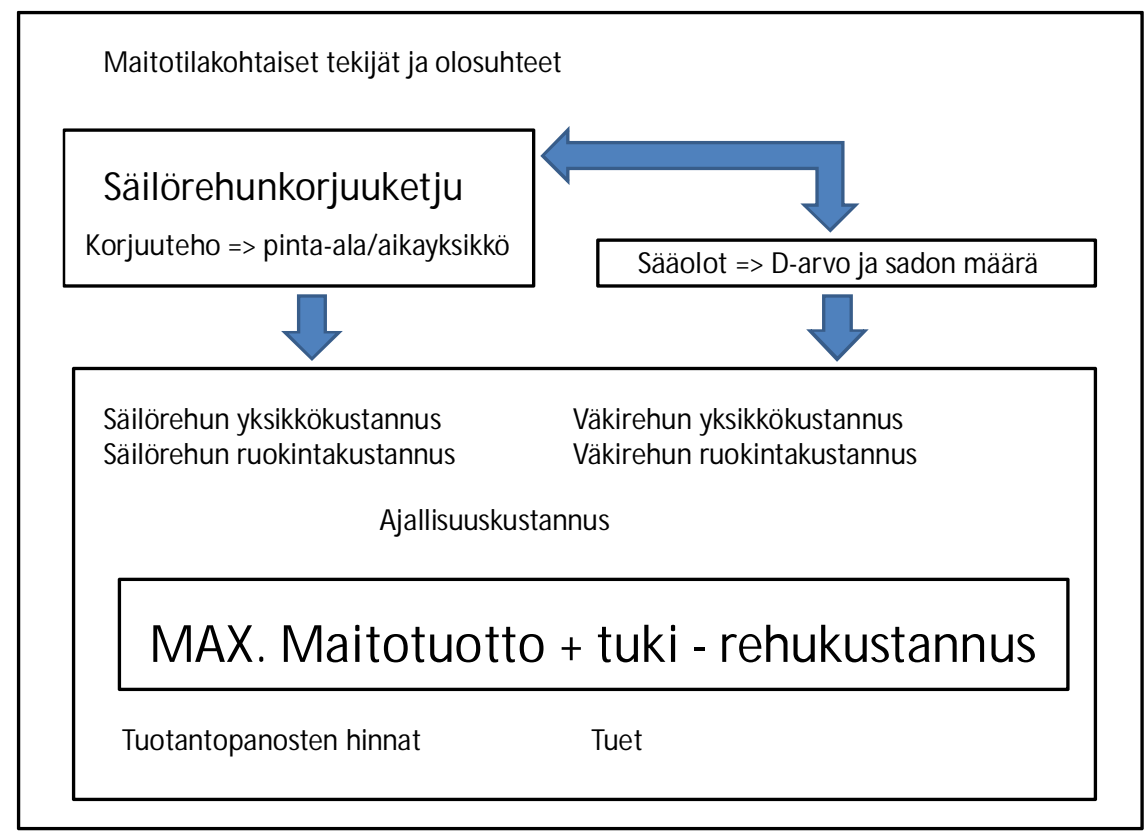

Kuvio 1. Tutkimuksen viitekehys.

Tilakohtaiset tekijät, tilan sijainti ja olosuhteet vaikuttavat säilörehunkorjuuketjun valintaan. Perusmalli laaditaan esimerkkitilojen peltolohkojen etäisyyksien ja lohkokokojen pohjalta. Säilörehun korjuuketju vaikuttaa korjuutehoon ja siten säilörehun sulavuuteen (D-arvo). Säilörehunkorjuuketjulla ja sääoloilla (nurmen sadon ja sulavuuden kehityksellä) on keskinäinen yhteys, mikä sisällytetään malliin. Mallilla voidaan selvittää myös säilörehunkorjuuta yhteistyönä. Tilatasolla vaihtoehtona on rehunkorjuun ulkoistaminen kokonaan tai osittain, millä voidaan tasoittaa työhuippuja (vrt. Karttunen 2004, 3-4; Karttunen ym. 2008, 45-49). Taloudellisesti optimaalinen säilörehunkorjuuprosessi ja rehujen optimaalinen käyttö lypsylehmien ruokinnassa ratkaistaan voiton maksimointi- ja/tai kustannusten minimointihypoteesin mukaisesti (Ryhänen ym. 1996; Seppälä ym. 2002). Maidontuottajan tavoitteena on siten maitotuoton (sisältää tuet) ja rehukustannuksen erotuksen maksimointi. 


\section{Aineisto ja menetelmät}

Tulokset perustuvat suunnittelumalliin, joka rakennettiin vastaamaan Etelä-Pohjanmaan säilörehun tuotanto-oloja. Ensimmäisen ja toisen säilörehusadon D-arvon ja kuiva-ainesadon kehitystä kuvaavat mallit on laadittu MTT:n nurmentuotantokokeiden perusteella (Rinne ym. 2010; Rinne \& Pitkänen 2011) ${ }^{1}$. Lypsylehmän rehuntarve määritettiin MTT:n ruokintakokeiden ja kirjallisuuden perusteella (Khalili ym. 2005; Kuoppala ym. 2008, 2009; Rinne ym. 1999; Sairanen ym. 1999, 2009, 2010a ja b)2 . Mallissa maitotuotos lehmää kohti pidetään esimerkkitiloilla samalla tavoitetasolla, joka on $9000 \mathrm{~kg}$ EKM (energiakorjattua maitoa) vuodessa. Rehujen tarve määritettiin siten, että kunkin D-arvon mukaisella säilörehulla ja sitä vastaavalla väkirehumäärällä kyseinen maitotuotos on mahdollista saavuttaa. Esimerkkitiloiksi valittiin 54, 108 ja 162 lehmän tilat ja neljä erilaista säilörehun korjuuketjua ${ }^{1}$ :

1) NK1: $38 \mathrm{~m}^{3}$ pohjakuljettimella varustettu noukinvaunuketju, jossa niitto, karhotus ja korjuu toteutetaan 6 metrin työleveydellä.

2) NK2: $50 \mathrm{~m}^{3}$ pohjakuljettimella varustettu noukinvaunuketju, jossa niitto, karhotus ja korjuu toteutetaan 9 metrin työleveydellä.

3) AS: Ajosilppuriketju, jossa rehun kuljetus- ja säilöntäkapasiteetti eivät rajoita ajosilppurin työsaavutusta. Niitto, karhotus ja korjuu toteutetaan 9 metrin työleveydellä. Ajosilppuri on oletettu hankitun käytettynä.

4) PKY: Paalainkäärin -yhdistelmä, jossa niitto, karhotus ja korjuu toteutetaan 6 metrin työleveydellä. Korjuun yhteydessä paalit siirretään pellon laitaan ja kiireajan ulkopuolella talouskeskukseen traktorin ja paalikärryn yhdistelmällä.

Kustannuslaskennan avulla selvitettiin vaihtoehtoisten korjuuketjujen kustannukset, minkä pohjalta määritettiin säilörehun tuottamisen yksikkökustannukset. Laskelmissa käytettiin vuoden 2011 tuki- ja hintatietoja. Mallia laadittaessa tehtiin seuraavat yksinkertaistavat oletukset:

1. Maidon tuotostaso pidetään vakiona ja se on $9000 \mathrm{~kg}$ EKM/lehmä/vuosi.

2. Sadon D-arvo ja kuiva-ainesato muuttuvat päivittäin, mutta pysyvät samana aina tiettynä korjuupäivänä (keskiarvo-oletus).

3. Kesäsadon $n$. päivänä korjattu pinta-ala on samansuuruinen kuin kevätsadon $n$. päivän pintaala.

4. Korjuuteho (ha/h) määräytyy kevätsadon mukaan. Kevätsadon D-arvo muuttuu nopeimmin, jolloin korjuutehoa tarkastellaan sen perusteella.

5. Korjuutehoon (ha/h) vaikuttaa lohkojen koko ja niiden etäisyys tilakeskuksesta.

6. Sadon määrällä ei ole vaikutusta korjuukoneen ajonopeuteen, jolloin sillä ei ole vaikutusta korjuutehoon (ha/h), mutta korjattu määrä hehtaaria kohti kasvaa. Tämä lähtöolettamus tehtiin, sillä korjuukoneiden laskennalliset työtehot on määritetty suuremmille sadoille kuin satomallista saadut.

7. Hehtaarikohtainen sadon lisäys kasvattaa kuljetus- ja varastointikustannuksia sadon suhteessa.

8. Korjuutehossa on huomioitu mahdolliset rikkoutumiset ja lohkolta toiselle siirtymiset kertoimella 0,90 .

9. Sopivan teholuokan traktori on aina saatavilla korjuuketjun kuhunkin osaan.

10. Niitto ja karhotus eivät viivästytä korjuutyön aloittamista.

11. Päivässä voidaan tehdä 12 tuntia töitä ja työvoimaa on saatavilla tarpeen mukaan.

12. Nurmen uudistukseen tarvittava ala on 25 prosenttia peltoalasta.

Lisäksi oletetaan, että D-arvon vaihtelusta huolimatta rehun laatu on muilta osin moitteetonta. Tarkastelussa sovelletaan ainoastaan kahden korjuukerran käytäntöä.

\footnotetext{
${ }^{1}$ Ks. tarkemmin Sipiläinen, Ryhänen, Karhula, Rinne \& Suokannas 2012.

${ }^{2}$ Eri tekijöiden vaikutuksia lypsylehmien syöntiin ja tuotokseen on yksityiskohtaisesti tarkasteltu seuraavissa mm. artikkeleissa: Huhtanen ym. 2007, 2008, 2009, 2011a, 2011b; Huhtanen \& Nousiainen 2012; Nousiainen ym. 2011.
} 


\section{Tulokset}

Suunnittelumallilla laskettiin aluksi perusratkaisut. Ensimmäisen sadon korjuu aloitetaan 10. kesäkuuta, jolloin satomallin tuottama D-arvon odotusarvo on $710 \mathrm{~g} / \mathrm{kg}$ ka ja korjuuta voidaan tarvittaessa jatkaa D-arvoon $620 \mathrm{~g} / \mathrm{kg}$ ka. Keskimääräinen lohkokoko on 2 hehtaaria ja peltojen keskimääräinen etäisyys tilakeskukseen on 54 lehmän tilalla kilometri, 108 lehmän tilalla kolme kilometriä ja 162 lehmän tilalla viisi kilometriä. Ensimmäisen ja toisen sadon korjuuväli on 40 tai 50 päivää. Taulukossa 1 esitetään säilörehun korjuuseen kuluva aika ja taloudellinen tulos €/100 kg EKM. Taloudellista tulosta mitataan erotuksella, jossa maitotuoton ja tilan tukien summasta vähennetään säilö- ja väkirehukustannus.

Taulukko 1. Esimerkkitilojen säilörehun korjuukertaa kohti kuluva aika ja taloudellinen tulos (maitotuotto + tuki - rehukustannus) €/100 kg EKM.

\begin{tabular}{lrrrr}
\hline & \multicolumn{4}{c}{ Säilörehun korjuuseen kuluva aika, pv } \\
& NK1 & NK2 & AS & PKY \\
\hline Korjuuväli 40 päivää & & & & \\
54 lehmää & 2,88 & 2,19 & 1,00 & 4,46 \\
108 lehmää & 7,64 & 5,86 & 1,98 & 8,39 \\
162 lehmää & 14,09 & 10,94 & 2,92 & 11,84 \\
Korjuuväli 50 päivää & & & & \\
54 lehmää & 2,29 & 1,73 & 0,79 & 3,58 \\
108 lehmää & 6,17 & 4,69 & 1,56 & 6,88 \\
162 lehmää & 11,70 & 8,93 & 2,32 & 9,94 \\
\hline
\end{tabular}

\begin{tabular}{lcccc}
\hline & \multicolumn{4}{c}{ Maitotuotto + tuki - rehukustannus €/100 kg EKM } \\
& NK1 & NK2 & AS & PKY \\
\hline Korjuuväli 40 päivää & & & & \\
54 lehmää & 29,71 & 27,56 & 26,22 & 28,20 \\
108 lehmää & 30,96 & 29,84 & 29,31 & 29,57 \\
162 lehmää & 30,96 & 30,27 & 30,04 & 30,42 \\
Korjuuväli 50 päivää & & & & \\
54 lehmää & 29,61 & 27,44 & 26,00 & 28,15 \\
108 lehmää & 30,93 & 29,80 & 28,97 & 29,68 \\
162 lehmää & 31,15 & 30,39 & 29,86 & 30,56 \\
\hline
\end{tabular}

NK1 'pieni' noukinvaunu, NK2 'suuri' noukinvaunu, AS ajosilppuri, PKY paalainkäärin -yhdistelmä.

Esimerkkitiloilla ja tehdyillä oletuksilla korjuukapasiteetiltaan pienin noukinvaunuketju (NK1) antaa parhaan taloudellisen tuloksen ja ajosilppuriketju (AS) huonoimman. Ajosilppuriketju on selkeästi nopein korjuuketju. Vaikka säilörehun D-arvo on tällöin suurin, korkeat konekustannukset kohottavat ajosilppuriketjun yksikkökustannusta siinä määrin, että se ei ole kilpailukykyinen yksittäisellä maitotilalla. Pieni noukinvaunuketju on hitain, mutta sillä ehditään korjata säilörehu suurimmallakin (162 lehmän tila) tilatyypillä ilman, että rehun D-arvo romahtaa (sääriskiä ei laskelmassa huomioitu). Tilakoon kasvaessa korjuumäärän kasvu alentaa yksikkökustannusta, mutta vastaavasti oletettu kuljetusetäisyyden kasvu kohottaa sitä. Tästä syystä yksikkökustannuksen alentuminen jää suhteellisen pieneksi tilakoon kasvaessa.

Kuljetusetäisyyden kasvu pienentää huomattavasti noukinvaunuketjujen työsaavutusta. Pitkä korjuuaika kasvattaa puolestaan noukinvaunuketjujen sääriskiä muihin ketjuihin verrattuna. Suunnittelumallin mukaan lohkojen etäisyydellä tilakeskuksesta onkin merkittävä vaikutus taloudelliseen tulokseen, joten tilusjärjestelyt ovat tärkeitä yksikkökustannusten pitkän aikavälin hallinnan kannalta. 
Tulosten herkkyyttä tutkittiin mm. lohkojen etäisyyttä, koneketjuja, hintoja ja olosuhteita muuttamalla sekä korjuun aloitusaikaa myöhästyttämällä. Herkkyystarkastelut tehtiin muuttamalla yhtä tekijää kerrallaan.

Herkkyystarkastelun mukaan säilörehun yksikkökustannukset kohoavat kuljetusetäisyyden kasvaessa mutta alenevat tilakoon kasvaessa. Noukinvaunuketjujen työteho pienenee selvästi lohkojen etäisyyden kasvaessa. Etäisyyden kasvulla ei ole samanlaista vaikutusta paalainkäärin -yhdistelmän ja ajosilppurin korjuutehoon. Paalien siirto tapahtuu korjuujakson ulkopuolella ja ajosilppuriketjuun lisätään kuljetusyksiköitä tarpeen mukaan. Etäisyyden kasvu lisää myös näissä korjuuketjuissa kuljetukseen kuluvaa aikaa ja kuljetuskustannuksia, vaikka varsinainen sadon korjuu ei hidastukaan.

Ensimmäisen korjuun aloitusta viivästytettäessä tai korjuuaikaa pidennettäessä kuiva-ainesato kasvaa, rehun sulavuus huononee, väkirehun tarve kasvaa ja tarvittava säilörehuala pienenee. Vastaavasti korjuuseen kuluva aika pitenee, kun ensimmäisen ja toisen sadon korjuuväliä lyhennettäessä toisen sadon osuus kuiva-ainesadosta pienenee ja korjuualan tarve kasvaa.

Jos maidontuottaja aloittaa sadonkorjuun kaksi tai neljä päivää perusmallia myöhemmin, koko sadon D-arvo laskee vastaavasti keskimäärin 10 tai $20 \mathrm{~g} / \mathrm{ka} \mathrm{kg}$. Korjuun siirtyessä myöhemmäksi säilörehualan tarve vähenee hehtaarisadon kasvaessa. Taloudellinen tulos heikkenee alle $10 €$ lehmää kohti, kun korjuun aloitusta myöhästytetään kahdella päivällä. Neljän päivän viivästyttäminen heikentää taloudellista tulosta noin $20 €$ lehmää kohti. Ensimmäisen ja toisen sadon korjuuvälin pituuden säätämisellä 40 ja 50 päivän välillä on vain vähäinen merkitys taloudellisen tuloksen kannalta.

Väkirehun hintamuutoksen vaikutusta tarkastellaan tässä yhteydessä kustannusten minimointiongelmana 9000 EKM kg tuotostasolla ottamatta huomioon tuotostason sopeuttamista, joka rehun ja maidon hintasuhteen muutoksesta myös aiheutuisi. Jos väkirehun hintaa nostetaan oletetusta $50 \%$, kaikilla esimerkkitiloilla ylijäämä pienenee 4-5 senttiä maitokiloa kohti. Tällöin 40 päivän korjuuväli tuottaa paremman tuloksen kuin 50 päivän korjuuväli. Nopea ajosilppuriketju hyötyy muutoksesta suhteessa muihin ketjuihin, mutta hintamuutoksesta huolimatta se ei tuota suurinta ylijäämää.

Yhteistyöllä on mahdollista saavuttaa kilpailuetua. Esimerkiksi kolme 54 lehmän tilaa voi saavuttaa 1-3 sentin lisäkatteen maitokiloa kohti, jos korjuu tehdään yhteistyönä. Alle 50 lehmän maitotiloilla yksikkökustannuksia voidaan alentaa vieläkin enemmän. Ajosilppurin korjuuteho mahdollistaa suurten maitotilojen yhteistyön yksikkökustannusten alentamiseksi. Jos hankitaan vaikkapa käytetty ajosilppuri kolmen 108 lehmän tilan säilörehun korjuuta varten, korjuuseen kuluu noin kuusi päivää, jolloin jää myös riskivaraa. Toimintavaihtoehdon tuottama taloudellinen tulos ylittää selvästi muiden vertailtujen ketjujen tuottaman taloudellisen tuloksen tässä yrityskokoluokassa.

Tehokkaiden säilörehun korjuuketjujen hyödyntäminen suosii tilojen välistä yhteistyötä tai urakoitsijoiden käyttöä. Korjuuajan pidentymisestä huolimatta taloudellista tulosta voidaan parantaa, koska konekustannukset laskevat huomattavasti. Samalla maitotilan kokonaistuottavuus kohoaa, mikä mahdollistaa yksikkökustannusten pienentämisen ja kannattavuuden parantamisen. Yhteistyöllä ja ulkoistamisella voidaan tasata myös työhuippuja. Laskelmien mukaan omien koneiden käyttö voi kilpailla taloudellisesti urakoinnin tai yhteistyön kanssa vasta yli 100 lehmän tiloilla. Se edellyttää, että työvoimaa on riittävästi käytettävissä.

\section{Johtopäätökset}

Pitkän aikavälin strategisessa suunnittelussa muuttuviksi tekijöiksi on otettava myös säilörehun korjuukoneet, varastot, peltoala ja työnmenekki. Säilörehun korjuussa taloudellisesti parasta ratkaisua etsittäessä on huomioitava koneista aiheutuvien kustannusten ja (biologisesti) optimaalisesta korjuuajankohdasta poikkeamisesta aiheutuvien kustannusten yhteisvaikutus. Tämän tutkimuksen perusteella koneiden käyttöasteen nostolla ja työn säästöllä yksikkökustannusta voidaan pääsääntöisesti alentaa enemmän kuin nopean korjuun tuottamasta korkeammasta D-arvosta hyödytään. Investoivan maidontuottajan kannattaa valita sellainen säilörehun tuotantomenetelmä ja lehmien ruokinta, jolla saavuttaa parhaan kokonaistaloudellisen tuloksen. Hän valitsee säilö- ja väkirehuyhdistelmän, joka sopii parhaiten strategiaan, sillä väki- ja säilörehu ovat tietyissä rajoissa toisillaan korvattavissa.

Talouden näkökulmasta strategisia päätöksiä ei voida perustaa yksittäisiin teknisiin tunnuslukuihin kuten D-arvoon, vaikka se onkin hyvä indikaattori nurmikasvuston sulavuuden kehityksestä. Säilörehun tuotantoon kuten muuhunkin tuotantoon liittyviä investointeja on tarkasteltava koko yrityksen toiminnan kannalta. Lyhyen aikavälin, esimerkiksi sisäruokintakauden, suunnittelun tulokset yleis- 
tettynä pitkän aikavälin suunnittelun pohjaksi voivat johtaa investoivaa maidontuottajaa tekemään virheellisiä valintoja. Pahimmillaan menetetään satopotentiaalia, varataan liikaa säilörehualaa ja lisätään pellon kysyntää, mikä nostaa hintoja ja heikentää maidontuottajan kokonaistaloudellista tulosta.

Eteläpohjalaisilla maitotiloilla tehdyt tehokkuustarkastelut osoittivat, että säilörehun D-arvon nousu vaikutti myönteisesti tekniseen tehokkuuteen korkeimpia D-arvotasoja lukuun ottamatta. Siten D-arvo näyttäisi olevan hyvä indikaattori teknisen tehokkuuden suhteen. Sen sijaan D-arvo ei ollut merkitsevä kustannustehokkuuden vaihtelua selittävä tekijä. Näin ollen D-arvo ei näytä kykenevän selittämään sitä, miten lähelle minimikustannusta tuotannossa päästään, kun panosten uudelleen allokoinnin mahdollisuuskin otetaan huomioon. Osin tämä liittyy myös tilakokoon, sillä säilörehun keskimääräisellä D-arvolla oli aineistossa taipumus laskea tilakoon kasvaessa. (Sipiläinen ym. 2012.)

Yhteistyö auttaa kilpailuedun saavuttamisessa. Esimerkkilaskelmien mukaan yhteistyön tuottama taloudellinen tulos ylittää selvästi muiden vaihtoehtojen tuottaman taloudellisen tuloksen, kun yhteistyö saadaan palvelemaan kokonaisuutta suunnitellusti. Vaikka säilörehun korjuuaika pidentyy, taloudellinen tulos paranee, koska yksikkökustannukset laskevat huomattavasti. Tehokkaat säilörehun korjuuketjut soveltuvat tilojen väliseen yhteistyöhön tai urakoitsijoiden käyttöön. Yhteistyöllä ja ulkoistamisella voidaan tasata myös työhuippuja. Laskelmien mukaan omien koneiden käyttö voi kilpailla taloudellisesti urakoinnin tai yhteistyön kanssa vasta yli 100 lehmän tiloilla, mutta sekin edellyttää lisätyövoiman hankintaa.

\section{Kirjallisuus}

Huhtanen, P. \& Nousiainen, J. 2012. Production responses of lactating dairy cows fed silage-based diets to changes in nutrient supply. Livestock Science 148:146-158.

Huhtanen, P., Rinne, M. \& Nousiainen, J. 2007. Evaluation of the factors affecting silage intake of dairy cows: a revision of the relative silage dry-matter intake index. Animal 1: 758-770.

Huhtanen, P., Rinne, M. \& Nousiainen, J. 2008. Evaluation of concentrate factors affecting silage intake of dairy cows: a development of the relative total diet intake index. Animal 2: 942-935.

Huhtanen, P., Rinne, M. \& Nousiainen, J. 2009. A meta-analysis of feed digestion in dairy cows. 2. The effects of feeding level and diet composition on digestibility. Journal of Dairy Science 92:50315042.

Huhtanen, P., Rinne, M., Mäntysaari, P. \& Nousiainen, J. 2011a. Integration of the effects of animal and dietary factors on total dry matter intake of dairy cows. Animal 5: 691-702.

Huhtanen, P., Nousiainen, J. \& Turtola, E. 2011b. Dairy farm nutrient management model: 2. Evaluation of different strategies to mitigate phosphorus surplus. Agricultural Systems 104: 383 - 391. Karttunen, J., Peltonen, M. \& Pentti, S. 2004. Säilörehun korjuuketjun suunnittelu. Rehuketjun kustannukset ja pullonkaulojen minimointi. Työtehoseuran maataloustiedote $568.8 \mathrm{~s}$.

Karttunen, J., Tuure, V.-M. \& Kaila, E. 2008. Maatilan töiden organisointi. Julkaisussa: Rikkonen, P., Harmoinen, T., Teräväinen, H. (toim.) Maatilayrityksen menestystekijät. Tieto tuottamaan 123. ProAgria Maaseutukeskusten Liiton julkaisuja nro 1056. Porvoo. 99 s.

Khalili H., Sairanen A., Nousiainen J. \& Huhtanen, P. 2005. Effect of silage made from primary or regrowth grass and protein supplementation on dairy cow performance. Livestock Production Science 96: 267-278.

Kuoppala K., Ahvenjärvi S., Rinne M. \& Vanhatalo A. 2009. Effects of feeding grass or red clover silage cut at two maturity stages in dairy cows. Dry matter and cell wall digestion kinetics. Journal of Dairy Science 92: 5634-5644.

Kuoppala, K., Rinne, M., Nousiainen, J. \& Huhtanen, P. 2008. The effect of cutting time of grass silage in primary growth and regrowth and the interactions between silage quality and concentrate level on milk production. Livestock Science 116: 171-182.

Nousiainen, J., Tuori, M., Turtola, E. \& Huhtanen, P. 2011. Dairy farm nutrient management model. 1. Model description and validation. Agricultural Systems 104: 371-382.

Rinne, M., Jaakkola S., Kaustell, K., Heikkilä, T. \& Huhtanen, P. 1999. Silages harvested at different stages of grass growth v. concentrate foods as energy and protein sources in milk production. Animal Science 69: 251-263.

Rinne, M., Huhtanen, P. \& Nousiainen, J. 2008. Säilörehun ja koko rehuannoksen syönti-indeksit auttavat lypsylehmien ruokinnan suunnittelussa. Maataloustieteen Päivät 2008. [verkkojulkaisu]. 
Suomen Maataloustieteellisen Seuran julkaisuja nro. 23. Toim. Anneli Hopponen. Julkaistu 9.1.2008. Saatavissa: http://www.smts.fi/mpol2008/index_tiedostot/Esitelmat/es086.pdf

Rinne, M., Pitkänen, T., Nyholm, L., Nousiainen, J. \& Huhtanen, P. 2010. Nurmiheinien ensimmäisen sadon sulavuuden ja sadon määrän mallit nurmirehuntuotannon hallintaan. Julkaisussa: Maataloustieteen päivät 2010 [verkkojulkaisu]. Suomen Maataloustieteellisen Seuran julkaisuja nro. 26. Toim. Anneli Hopponen. Julkaistu 11.1.2010. Saatavissa: http://www.smts.fi/jul2010/poste2010/136.pdf

Rinne, M. \& Pitkänen, T. 2011. Julkaisematon malli toisen sadon D-arvon ja kuiva-aineen kehityksestä. Maa- ja elintarviketalouden tutkimuskeskus.

Rinne, M. \& Sairanen, A. 2010. Nurmirehut ruokinnassa. Julkaisussa: Peltonen, S., Puurunen, T. \& Harmoinen, T. (toim.) Nurmirehujen tuotanto ja käyttö. Tieto tuottamaan 132. ProAgria Keskusten Liiton julkaisuja nro 1093. $98 \mathrm{~s}$.

Ryhänen, M., Huhtanen, P., Jaakkola, S. \& Ahvenjärvi, S. 1996. EU-jäsenyyden vaikutus maidontuotantoon. Julkaisussa: Ylätalo, M. (toim.) Maatalousyritysten sopeutuminen EU:ssa vallitseviin hintasuhteisiin. Helsingin yliopisto. Taloustieteen laitos. Julkaisuja nro 18. Maatalouden liiketaloustiede. $235 \mathrm{~s}$.

Sairanen, A. \& Juutinen, E. 2012. Säilörehun korjuuajan vaikutus lehmien säilörehun syöntiin ja maitotuotokseen. Karjatilan kannattava peltoviljely, KARPE-hanke. Loppuraportti. pp. 11-16. Saatavissa: http://www.karpe.fi/materiaalit/karpekirjasto/paatosjulkaisu.pdf

Sairanen, A., Nousiainen, J. I., \& Khalili, H. 1999. Korkean väkirehumäärän vaikutus maitotuotokseen ja tuotannon kannattavuuteen. Teoksessa: Mitä Suomi syö -ja millä hinnalla? Agro Food 1999. Agro Food ry/ Agronomiliitto ry. $7 \mathrm{~s}$.

Sairanen, A., Juutinen, E., Hyrkäs, M., Virkajärvi P. \& Suomela R. 2009. Julkaisematon. Säilörehun D-arvon muutoksen korvaaminen väkirehumäärää tai väkirehun valkuaispitoisuutta muuttamalla. 1. Säilörehun D-arvo 650 tai $700 \mathrm{~g} / \mathrm{kg}$ ka. KARPE-hanke 2009.

Sairanen, A., Juutinen, E., Hyrkäs, M., Virkajärvi P. \& Suomela R. 2010a. Julkaisematon. Säilörehun D-arvon muutoksen korvaaminen väkirehumäärää tai väkirehun valkuaispitoisuutta muuttamalla. 2. Säilörehun D arvo 600 tai $650 \mathrm{~g} / \mathrm{kg}$ ka. KARPE-hanke 2010.

Sairanen, A. Virkajärvi, P. \& Juutinen, E. 2010b. Karjatilan nurmirehun korjuuaikastrategiat. Julkaisussa: Maataloustieteen päivät 2010 [verkkojulkaisu]. Suomen Maataloustieteellisen Seuran julkaisuja nro. 26. Toim. Anneli Hopponen. Julkaistu 11.1.2010. Saatavissa:

http://www.smts.fi/jul2010/poste2010/116.pdf

Seppälä, R., Ryhänen, M., Sipiläinen, T., Rinne, M., Huhtanen, P. \& Suokannas, A. 2002. Säilörehu maitotilan taloudessa - pitkän aikavälin näkökulma. Julkaisussa: Ryhänen, M. \& Sipiläinen, T. (toim.) Nurmisäilörehu maitotilan taloudessa. Helsingin yliopisto. Taloustieteen laitos. Julkaisuja nro 35. Maatalouden liiketaloustiede. $103 \mathrm{~s}$.

Sipiläinen, T., Ovaska, S. \& Ryhänen, M. 2012. Tuottavuus, tehokkuus ja taloudellinen tulos eteläpohjalaisilla maitotiloilla. Julkaisussa: Sipiläinen, T. \& Ovaska, S. (toim.) Maitotilalle kilpailukykyä tuottavuutta ja tehokkuutta kehittämällä. MTT Raportti 78: 9-42.

Sipiläinen, T., Ryhänen, M., Karhula, V., Rinne, M. \& Suokannas, A. 2012. Säilörehun korjuuketjujen taloudellinen tarkastelu. Julkaisussa: Sipiläinen, T. \& Ovaska, S. (toim.) Maitotilalle kilpailukykyä tuottavuutta ja tehokkuutta kehittämällä. MTT Raportti 78: 43-68. 